\title{
Dermatological Manifestation in Coronavirus Disease 2019 Patients in Iraq
}

\author{
Anfal L. Al-Harbawi ${ }^{1 *}$, Qasim S. Al Chalabi ${ }^{1}$, Hala N. Alsalman ${ }^{2}$, Mohammad S. Saeed $^{3}$ \\ ${ }^{1}$ Department of Medicine, Dermatology Section, Arab Board of Dermatology (FABHS Dermatology and Venereology), Mosul \\ University, Mosul, Iraq; ${ }^{2}$ Department of Medicine, Dermatology Section, Iraqi Board of Dermatology (FIBMS Dermatology \\ and Venereology), Mosul University, Mosul, Iraq; ${ }^{3}$ Dermatology Section, Arab Board of Dermatology (FABHS Dermatology and \\ Venereology), Al Sadir Teaching Hospital in Misan, Basrah, Iraq
}

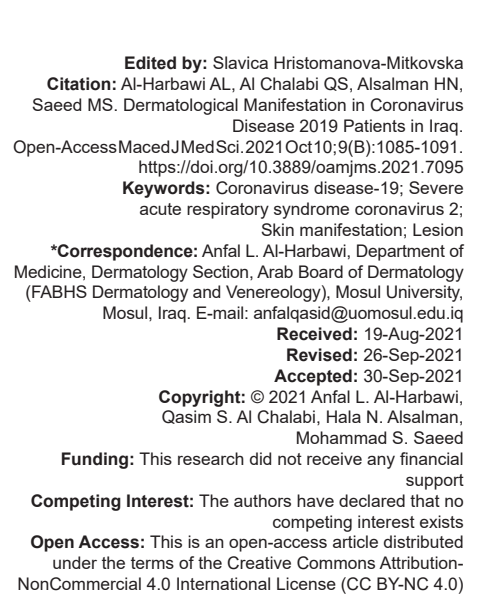

\section{Introduction}

In December 2019, an unprecedented RNA virus known as "severe acute respiratory syndrome coronavirus 2" (SARS-CoV-2) was first noted in Wuhan, China, in cases of unusual pneumonia. Subsequently, the disease caused by this virus has expanded at staggering spread leading up to a global pandemic [1]. It is usually presented as an upper respiratory tract infection, however, other organs including skin can be affected [1]. Moreover, collective data demonstrated that coronavirus disease (COVID-19)-related cutaneous manifestations were remarkably diverse [2], [3]. In respect to this aspect, many clinical patterns of COVID-19-associated skin lesions had recently been publicized. These include urticaria, maculopapular rash, vesicular eruptions, pseudo chilblains, herpes lesions, eczema, and other skin diseases, such lesions can coincide, proceed, or preceded the onset of COVID-19 clinical features [2], [3], [4].

\begin{abstract}
BACKGROUND: Coronavirus disease-19 (COVID-19) is a growing pandemic around the globe that was initially

AIM: This study aims to report the possible incidence of the cutaneous lesion in COVID-19 patients and to describe
various cutaneous manifestations and their correlation with other clinical features in COVID-19-positive patients to facilitate diagnosis and prognostications toward this virus. METHODS: This research was conducted as a cross-sectional study. Skin lesions photography and their analysis
were collected by dermatologists from 18 cities in Iraq between September 2020 and January 2021. The data were RESULTS: A total of 3117 confirmed COVID-19 cases were included in this study. Around 268 patients developed skin lesions with age ranged between 8 and 84 years. Of these skin lesions, $46.2 \%$ developed during the illness with minority erupting during the prodromal phase, while $38.8 \%$ appeared after hospitalization. The most common skin $(46 \%)$, followed by limbs, face, fingers, and toes. discovered in Wuhan in December 2019. Despite the relatively high incidence of cutaneous manifestations in remainder being candidiasis, oral thrush, chilblains, and other skin conditions. The most affected area was the torso
\end{abstract}

CONCLUSION: This study demonstrated the high incidence rate of dermatological lesions in different phases of COVID-19 with urticarial rash being the most frequent clinical pattern. 


\section{Aim}

The aim of the study was as follows: To report the possible incidence of the cutaneous lesion in COVID-19 patients. To describe various cutaneous manifestations and their correlation with other clinical features in COVID-19-positive patients to facilitate diagnosis and prognostications toward this virus.

\section{Patients and Methods}

This research was conducted as a crosssectional study, from September 30, 2020, to January 31, 2021, from different hospitals over 18 cities in Iraq, tens of dermatologist and physician had participated in the effort to collect cases and documented them by photos (three of the doctors had been infected in purpose to improve our knowledge to fight this virus). About 3148 COVD-19 positive were enrolled in the current study. Thirty-one patients were excluded from this study because they had a history of chronic skin diseases years before the illness started. Diagnosis of positive COVID-19 infection was confirmed by reverse-transcriptase polymerase chain reaction assay. A standardized questionnaire was used for each patient including (age, sex, disease duration, history of previous skin diseases, type of skin lesion, and time onset of the lesion in relation to other COVID symptoms). Photos were taken to the affected area after taking patient's permission. Their photographs were then reviewed by a group of three dermatologists to avoid bias. Accordingly, the results were grouped and later correlated with the rest of the patient's information for analysis using statistical package SPSS version 23.

\section{Results}

In the current study, 3117 patients were encountered, mean \pm SD of the patients' age was $58 \pm 0.8$ years (age range: 8-84 years). There were 1402 women and 1715 men confirmed to have SARS2 positive with a female-to-male ratio of 1:0.8.

A total of $268(8.58 \%)$ out of 3117 patients had different cutaneous manifestations 127 females and 141 males, with a female-to-male ratio of $1: 0.9$ and mean age was 48.5 years.

In $46.3 \%$ of these patients got the lesions at the same time of onset of COVID-19 symptoms, $38.8 \%$ showed the lesion days after hospitalization with a mean duration of 10 days, the rest showed the cutaneous manifestation a few days before the onset of COVID-19 symptoms. The latency period (the duration between the appearance of skin lesions and the other COVID-19 symptoms) was between 2 days before and 12 days after other symptoms (Table 1 ).

More than $36 \%$ of the patients presented with urticaria which started as an acute eruption of multiple different size wheals mainly over the trunk and extremities persisting $<24 \mathrm{~h}$, however, 10 of them had lesion for more than $24 \mathrm{~h}$ despite immediate treatment (Figure 1) accompanied with fever and cough. Regarding the onset of the urticrea lesion about $21.6 \%$ of them had lesions (3-5) days before of onset of other COVID 19 symptoms. The rest of the cases (27.9\%) presented with urticaria days after onset of COVID symptoms with a mean latency period of 5.3 days.

The second common lesion (27.9\%) was in the form of vesicular (herpetic) lesions presented as groups of monomorphic vesicles containing clear or hemorrhagic fluid widely distributed over the trunk with an erythematous background (herpetic like) (Figure 2) or as discrete vesicles varicella like (Figure 3 ) either before in $16 \%$ or after $38.6 \%$ or $45.3 \%$ during the symptomatic period of the disease.

Another 31 (11.6\%) patients presented with a maculopapular rash covering most of their trunk and

Table 1: The frequency of different dermatological manifestations encountered in the current study and their relation to other clinical parameters

\begin{tabular}{|c|c|c|c|c|c|c|c|c|c|}
\hline \multirow[t]{2}{*}{ Type of skin lesion } & \multicolumn{2}{|c|}{$\begin{array}{l}\text { Number } \\
\text { of cases }\end{array}$} & \multirow[t]{2}{*}{ Mean age/years } & \multicolumn{2}{|c|}{ Gender } & \multicolumn{3}{|c|}{ Onset in relation to other COVID-19 symptoms and signs } & \multirow[t]{2}{*}{$\begin{array}{l}\text { Median days of latency } \\
\text { period* }^{*}\end{array}$} \\
\hline & No. & $\%$ & & $\bar{F}$. & M. & $\begin{array}{l}\text { Before the appearance } \\
\text { of other symptoms }\end{array}$ & $\begin{array}{l}\text { With other symptoms in a } \\
\text { week duration }\end{array}$ & $\begin{array}{l}\text { After a week from } \\
\text { starting symptoms }\end{array}$ & \\
\hline Urticaria & 97 & 36.1 & 36 & 59 & 38 & 21 & 49 & 27 & 5.3 \\
\hline Vesicular lesion & 75 & 27.9 & 46 & 26 & 49 & 12 & 34 & 29 & 9.2 \\
\hline Maculopapular rash & 31 & 11.6 & 31 & 12 & 19 & 11 & 13 & 7 & 6.9 \\
\hline Pityriasis roses like & 5 & 1.9 & 32 & 3 & 2 & 2 & 2 & 1 & 5.6 \\
\hline Erythema multiforme & 8 & 3 & 45 & 5 & 3 & 0 & 1 & 7 & 9.1 \\
\hline Chilblains & 10 & 3.7 & 17 & 4 & 6 & 1 & 4 & 5 & 14.8 \\
\hline Vasculitis & 4 & 1.5 & 64 & 1 & 3 & 0 & 1 & 3 & 14.5 \\
\hline Ecchymosis & 4 & 1.5 & 35 & 1 & 3 & 0 & 0 & 4 & 7.6 \\
\hline Livedo reticularis & 3 & 1.1 & 42 & 1 & 2 & 0 & 3 & 0 & 12.2 \\
\hline Erythroderma & 1 & 0.4 & 54 & 0 & 1 & 0 & 1 & 0 & 11 \\
\hline $\begin{array}{l}\text { Ichthyosis-like } \\
\text { exfoliative dermatitis }\end{array}$ & 1 & 0.4 & 69 & 0 & 1 & 0 & 1 & 0 & 9 \\
\hline Acute generalized pustular dermatosis & 1 & 0.4 & 71 & 1 & 0 & 0 & 1 & 0 & 13 \\
\hline Candidiasis and oral thrush & 19 & 7.1 & 69 & 12 & 7 & 1 & 6 & 12 & 11 \\
\hline Boils & 9 & 3.4 & 58 & 2 & 7 & 1 & 2 & 6 & 7.5 \\
\hline Total & 268 & 100 & 47.5 & 127 & 141 & 49 & 118 & 101 & \\
\hline
\end{tabular}




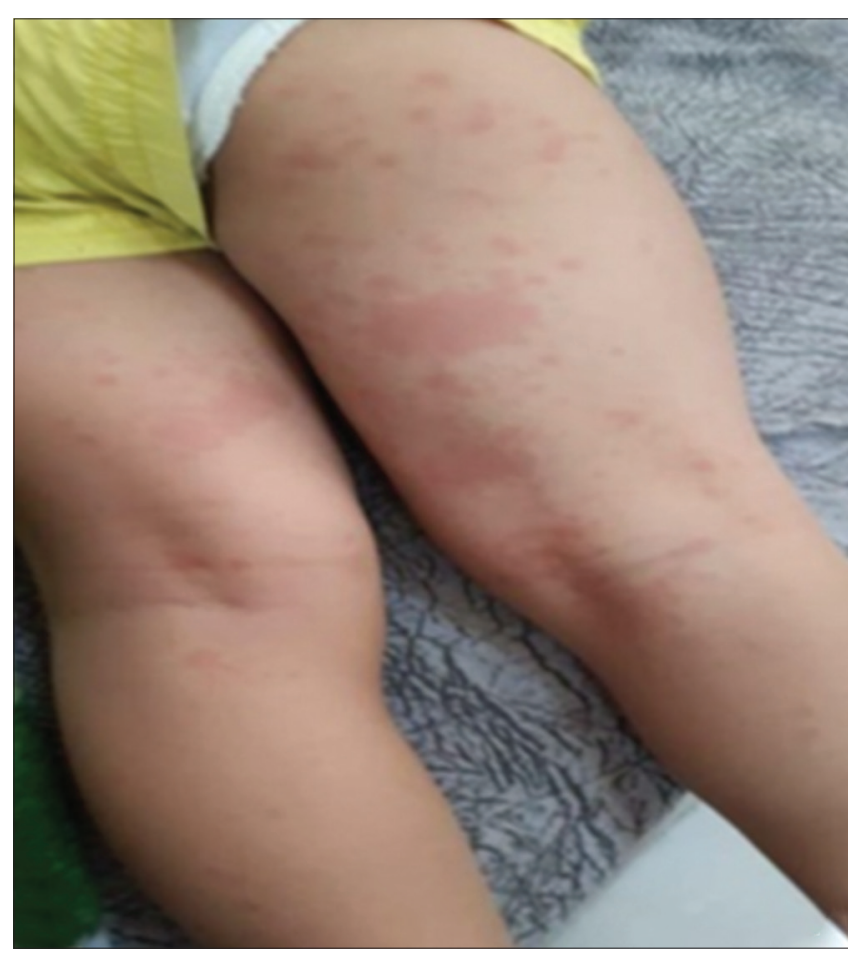

Figure 1: Urticarial lesion multiple variable sized wheals predominantly on the trunk and extremities

extremities with variable thickness of scaling (Figure 4). Five cases $(1.9 \%)$ showed lesions resembling pityriasis rosea (Figure 5), $13(41.9 \%$ ) of them developed the rash concomitant with the onset of COVID-19 symptoms, whereas $7(22.5 \%)$ got the rash a few days after starting COVID-19 symptoms with a mean duration of 6.9 days.

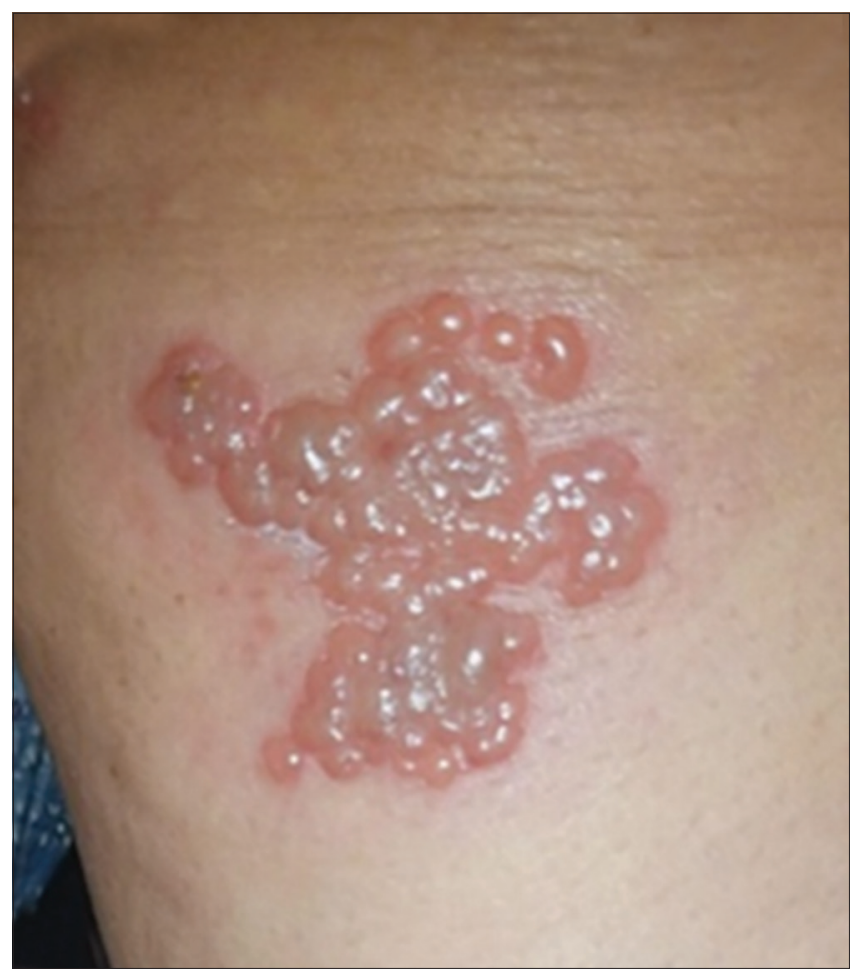

Figure 2: Multiple vesicles on erythematous base ( herpes like)

Vasculitis and thrombolytic defect presented in many shapes like chilblain which was seen in $3.73 \%$

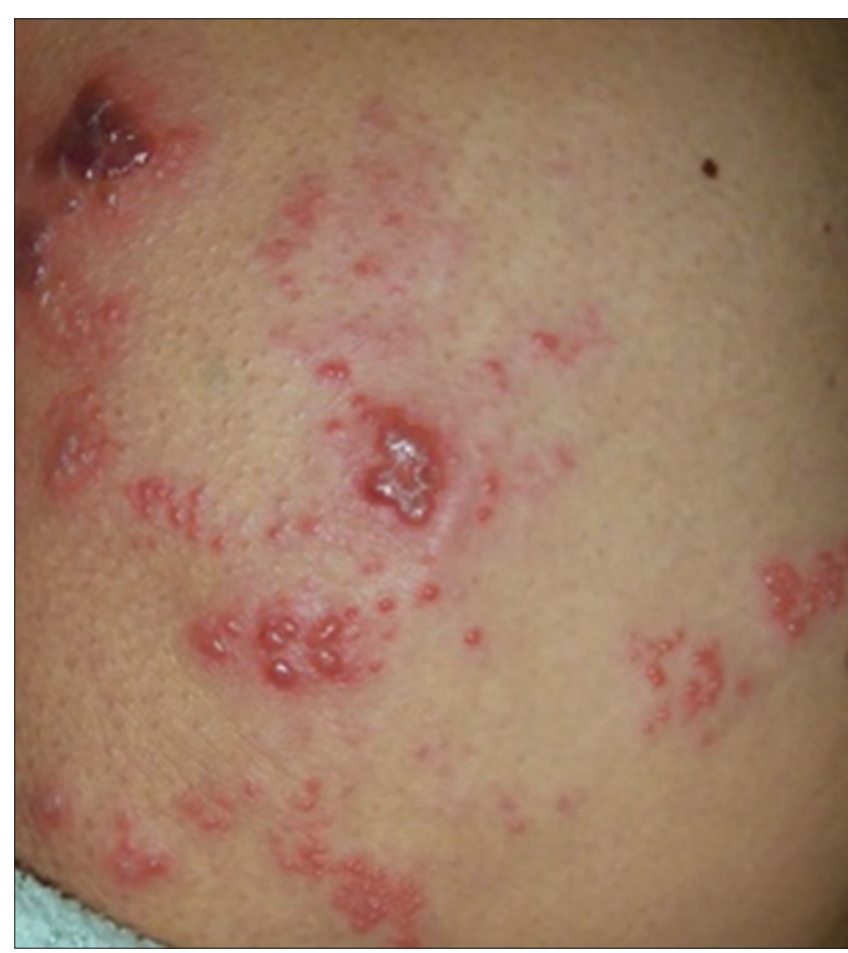

Figure 3: Polymorphic skin lesions (varicella like)

of cases (as red to violet papules, macules, plaques, or even as nodules in the body sites exposed to coldlike fingers and toes with pain, itching, and burning sensations), as shown in Figure 6, or as livedo reticularis

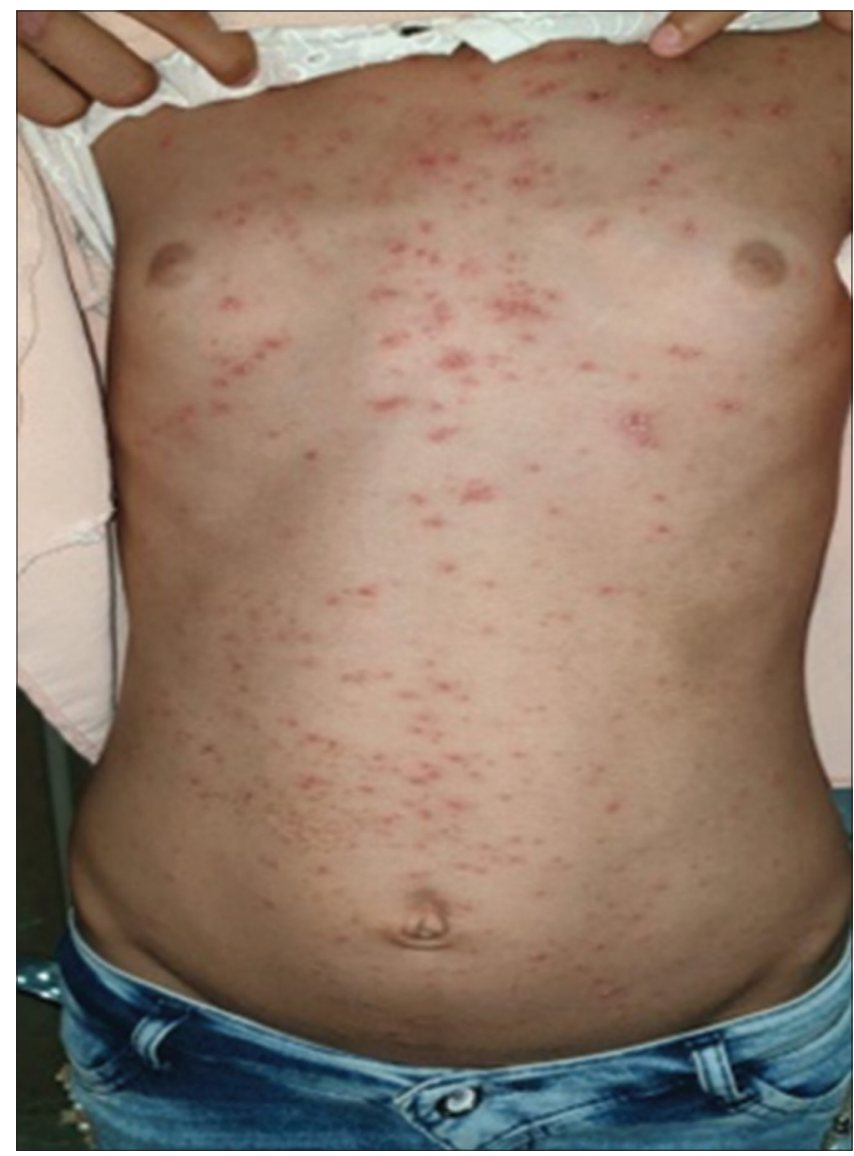

Figure 4: Multiple erythematous macules and papules predominantly on the trunk 


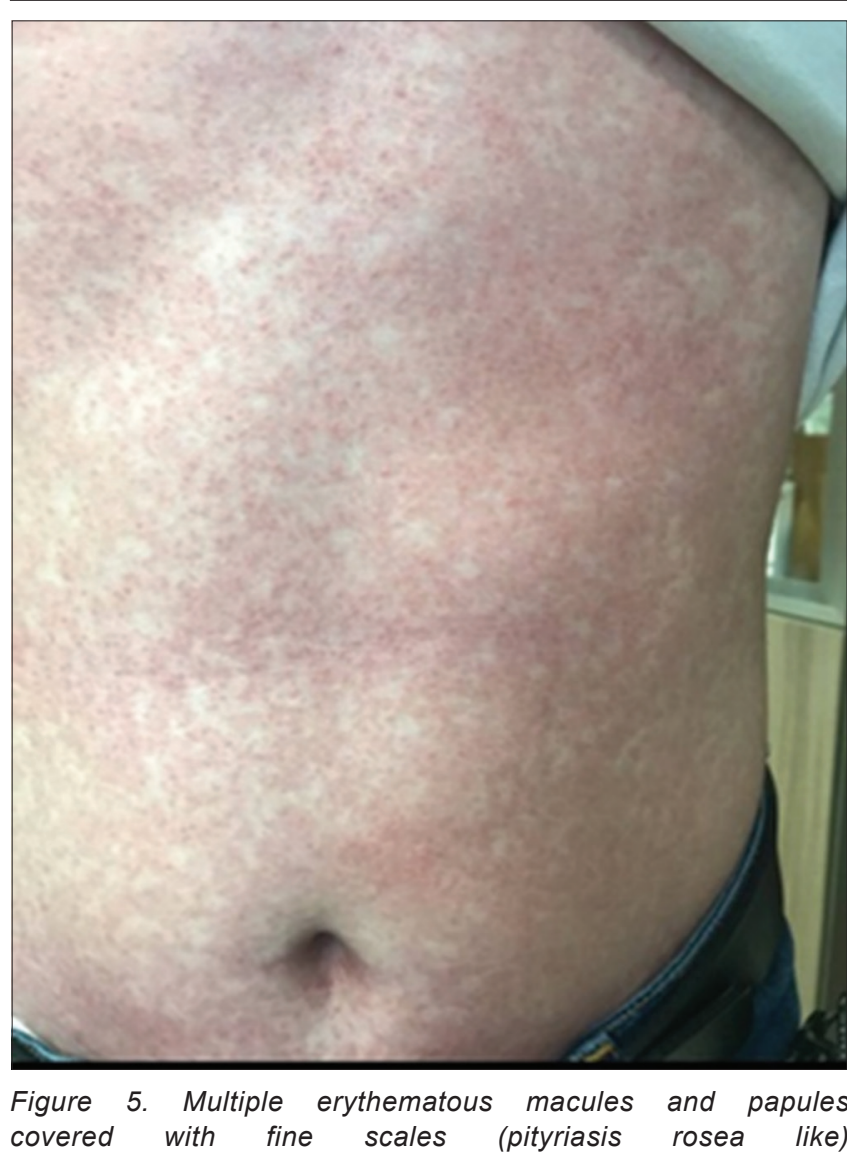

like" with punched out ulcers in $1.19 \%$, as shown in Figure 7 or as petechial and ecchymotic lesions in $1.5 \%$ of cases (Figures 8 and 9).

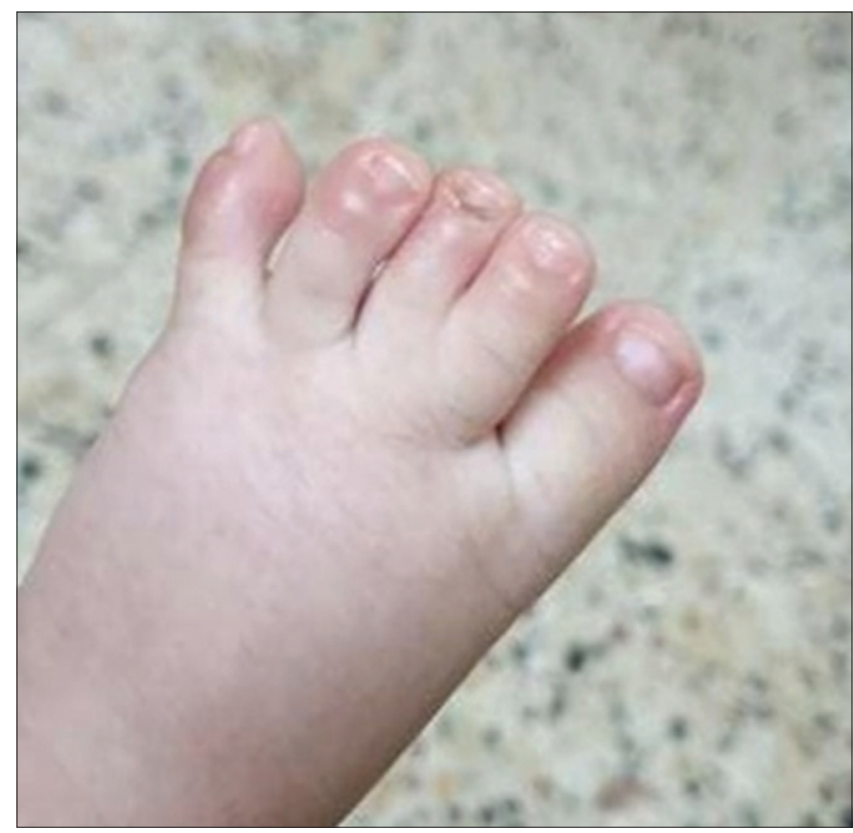

Figure 6: Erythematous to violaceous macules and nodules on the toes

In $3 \%$ of cases, the patients presented as multiple erythematous to violaceous macule or papule with targetoid appearance, few show central ulceration or vesicles and bullae as erythema multiforme like (Figure 10).

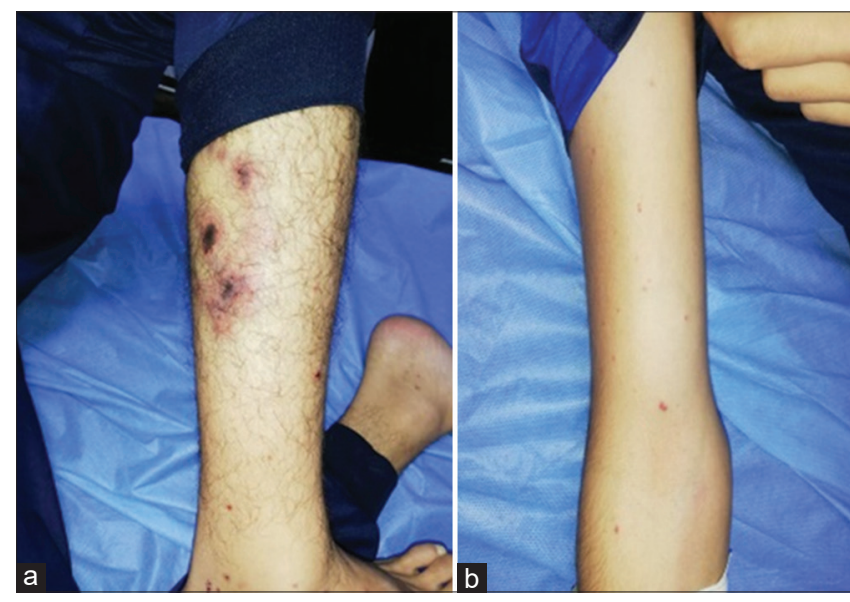

Figure 7: $(a$ and $b)$ Violaceous papules and ulcers on extremities

We reported unusual cases, one patient complains of generalized ichthyosis like exfoliating dermatitis, as shown in Figure 11, the other one as acute generalized pustular dermatosis, as shown in Figure 12, and the last one as erythroderma, as shown in Figure 13.

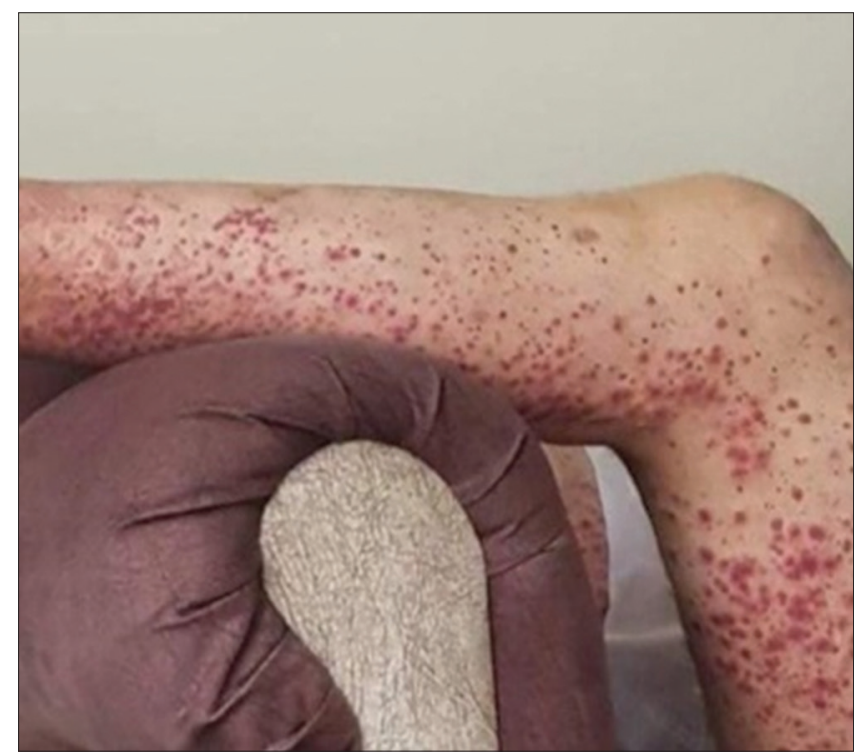

Figure 8: Numerous non blanchable purple papules predominantly on the lower limbs (Henoch Scnolein purpura like)

Another 28 patients showed different lesions of secondary microbial infection as bacterial and fungal infection, as shown in Figure 14.

The trunk was the most common region $46 \%$ of the patients involved by those dermal manifestations, followed by the extremities, face, fingers, and toes.

\section{Discussion}

Cutaneous manifestations had been frequently described in many viral infections such as measles, herpes virus, likewise, and skin lesions 


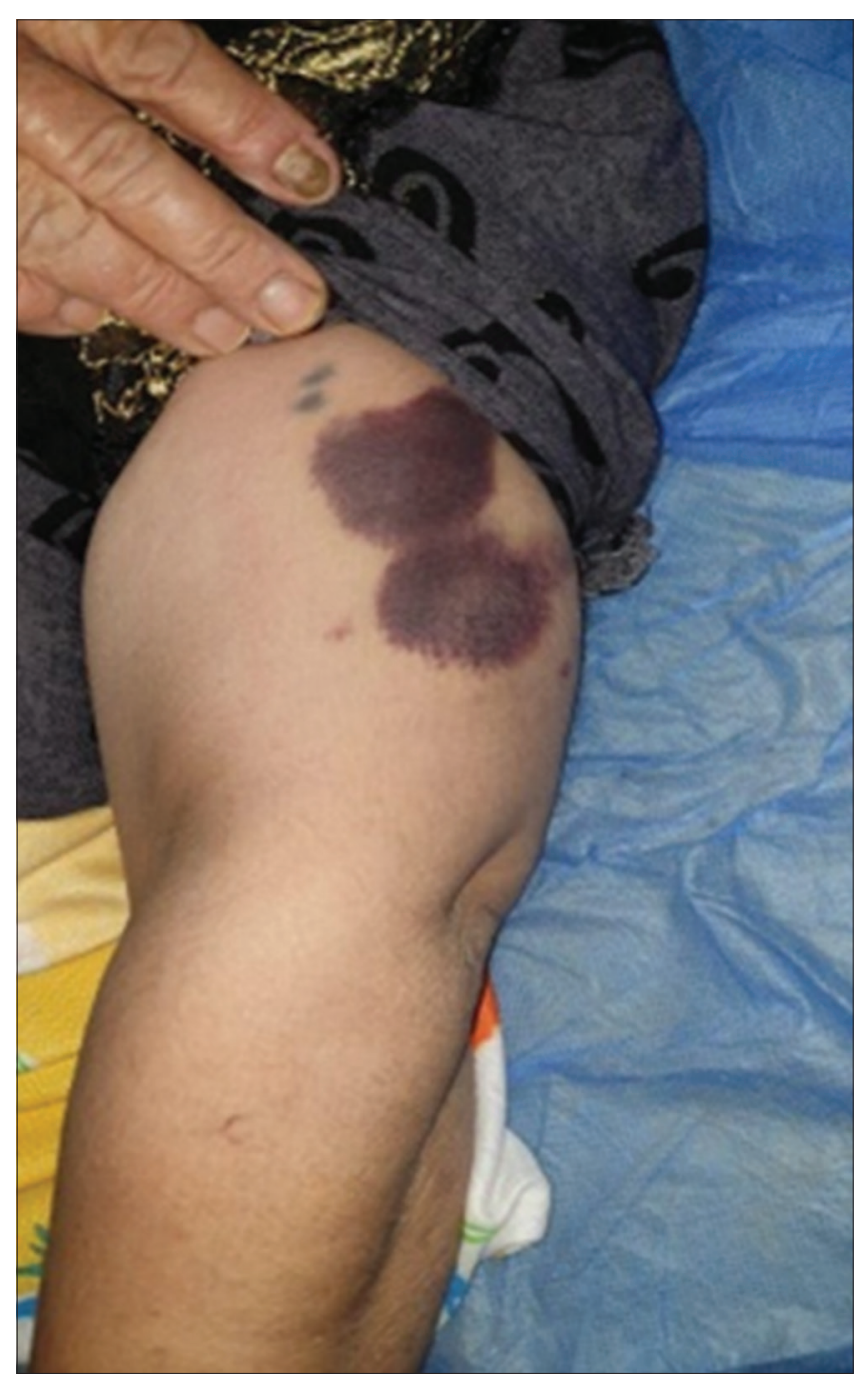

Figure 9: Multiple variable size ecchymotic lesions.

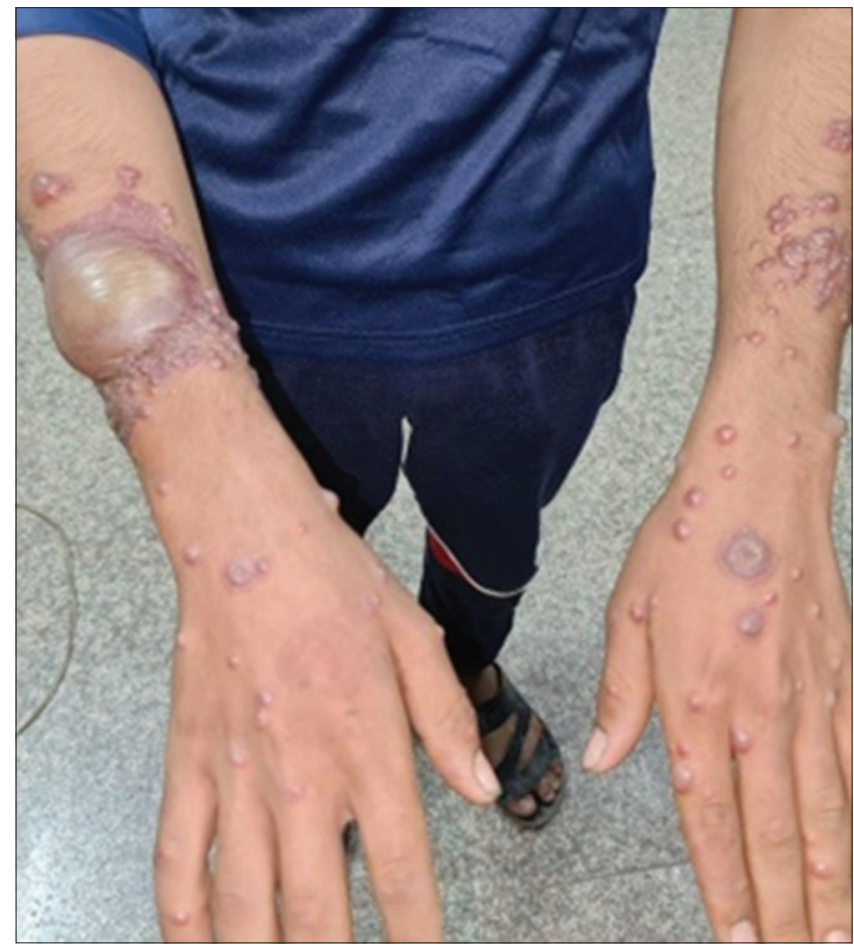

Figure 10: bilateral symmetrical purple targetoid lesions with few central bullae on the upper limbs had been increasingly reported in association with COVID-19 [4].

To the best of our knowledge, this is by far the largest study to investigate the incidence of dermatological lesions in COVID-19-positive patients supported by skin lesions photography and their description outlined by experienced dermatologists.

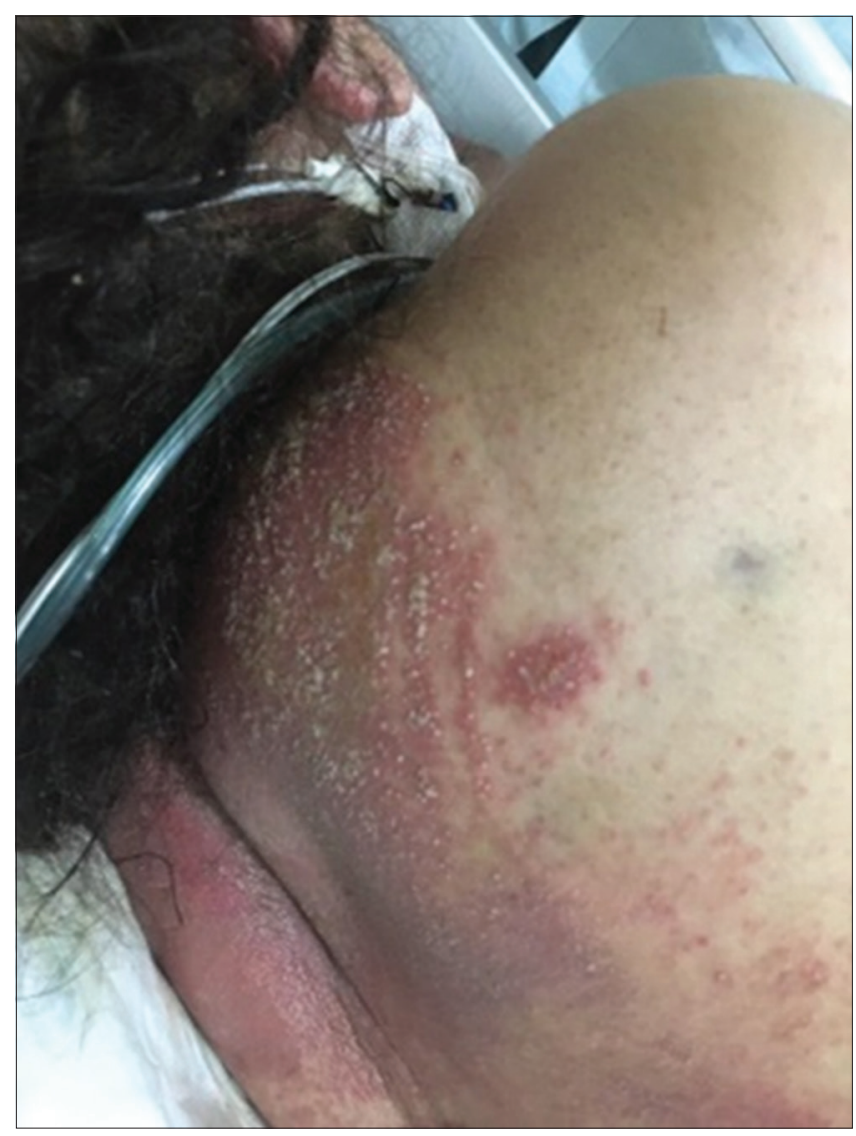

Figure 11: The skin showed fine scales on all over the body In this study, various cutaneous manifestations were demonstrated in $8.6 \%$ of COVID-19-positive

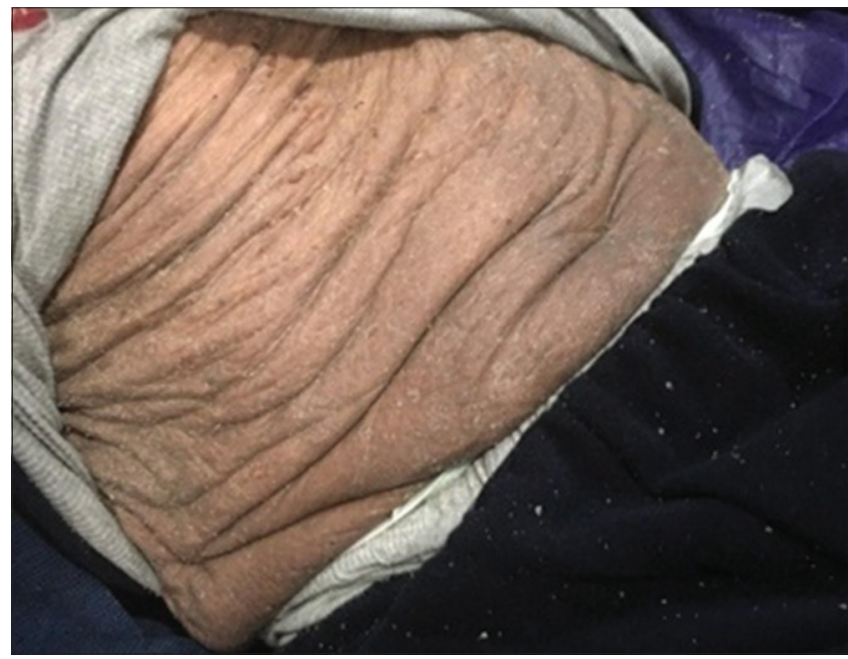

Figure 12: The skin showed multiple pustules on erythematous patch with crustation

patients. This was nearly 9-fold higher than those reported by Gucan et al. in China (1\%) [5], however, this 

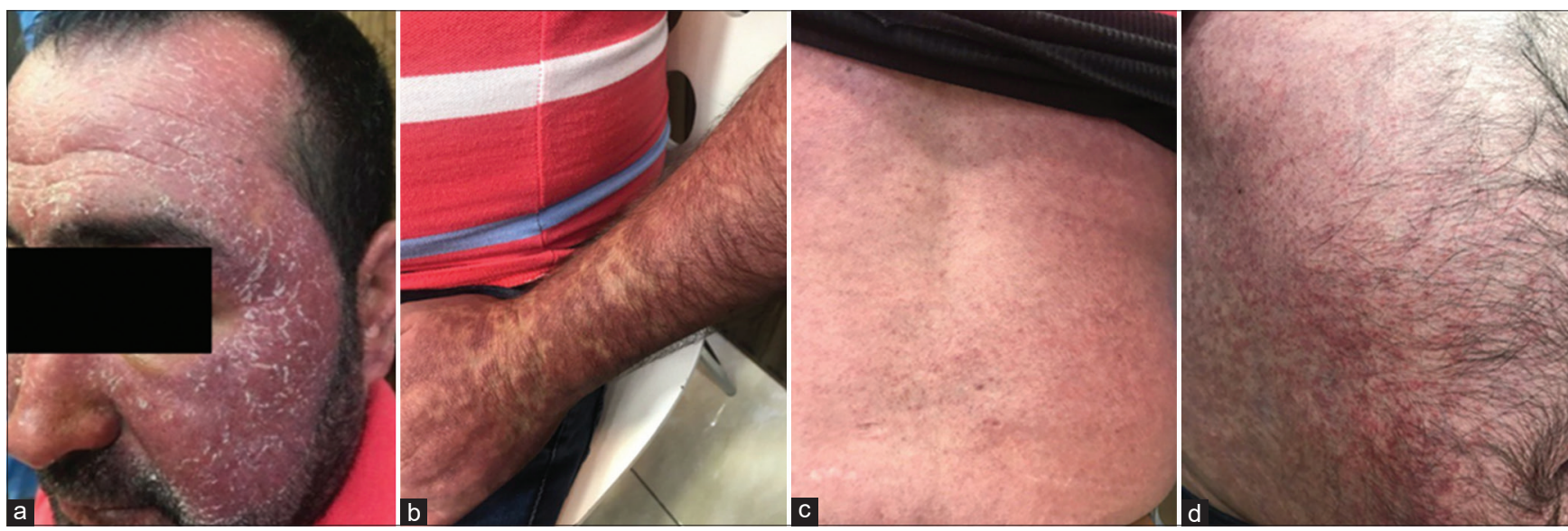

Figure 13: (a-d) Generalized erythematous skin covered with fine scales.

was lower than those reported in the Italian literature [6]. This could be explained by an inadequate recording of skin findings in COVID-19 patients at the onset of the outbreak. Due to the remote consultation using mobile phone or other media rather than face- to-face consultation as safety measures to prevent the spread of this fast-growing pandemic [2], [5], while in our research, more than 20 dermatologist examined and recorded the cases. Moreover, obtaining tissue samples or skin lesion photographs were challenging, especially due to strict isolation rules.
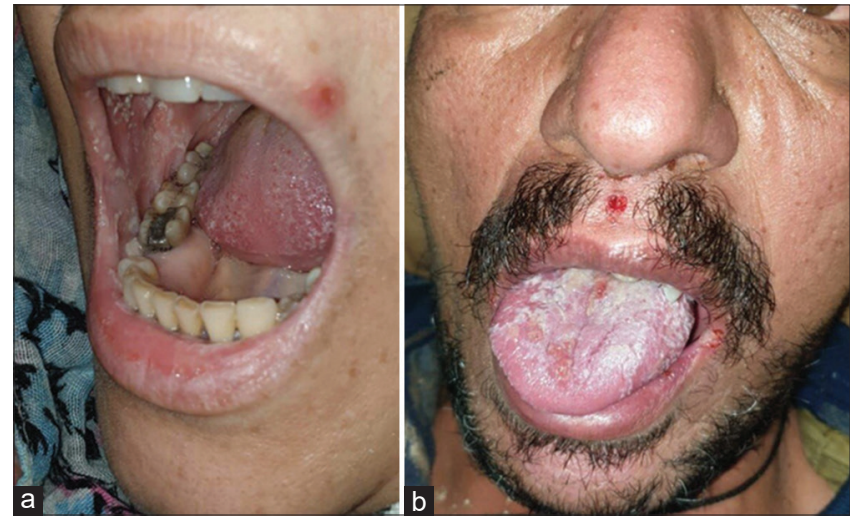

Figure 14: $(a, b)$. Oral thrush

Unsurprisingly, cutaneous lesions were predominately observed on the trunk and around $46 \%$ of these lesions erupted at the time of onset of the disease. These findings agreed with other literature [7].

In this study, the most frequent clinical pattern of skin rashes was generalized urticaria in $36 \%$ of the patients, also in other studies [2], urticaria was the most common dermatological presentation but still less frequent than our study may be due to the eruption of some dermatological lesions such as urticaria and pustular rash in the early days of starting treatment suggested the possibility of a drug reaction to COVID19 treatment, particularly hydroxychloroquine which was overly used at the beginning of the outbreak [8] but we found that $20.6 \%$ of cases had urticaria before other symptoms appeared and most cases was between 8 and 26 years old. According to Schulkes et al., 2020, non-hereditary angioedema might be related to the rise in mast cell activation and bradykinin release as we reported in twelve patients [9].

About $28 \%$ of patients of this study had vesicular lesions, as in another research done in an Italian multicentric study that recorded vesicular lesions in $18.2 \%$ of cases [10]. The idea of this papulovesicular exanthem might be associated with COVID-19 or due to reactivation of a member of the Herpesviridae family, still in debate, but our work found that lesions not presented as typical form or sites of herpetic lesions, and lesions appeared more extensive and responded to COVID-19 treatment.

Regarding maculopapular eruptions (macular erythema, morbilliform exanthem, and papulosquamous lesions [pityriasis rosea like]) had been reported in about $16 \%$ of patients of this study, supported by a review done by Giulia et al. show about $21 \%$ of cases had a maculopapular lesions [11].

In our study, we reported different vascular lesions (chilblain, vasculitis, ecchymosis, and livedo vasculitis) similar to other articles, but we found that the incidence of pseudo chilblain lower in-comparison to other researches [11] may due most of them done in winter in cold weather while we collected cases in summer in hot environments.

Finally, we reported three cases of erythroderma, acute generalized pustular dermatosis, and ichthyosis-like exfoliative dermatitis. No other researchers identified but the most possible explanation was what Gürkan et al. supporting in their literature as the possible correlation of the activated Langerhans cells and the inflammatory process leading to activation of keratinocyte and consequently diffuse spongiosis in the epidermis, in addition to lymphohistiocytic dermal infiltration [12]. Hamming et al. revealed that ACE2, a receptor for SARS virus, is also present in the basal cell layer of the epidermis and extending to the basal cell layer of hair follicles which could explain the COVID-19related dermatological manifestations [13]. 
In this study, about $10 \%$ of patients had suffered an exacerbation of various bacterial, fungal skin infections, oral moniliasis, acne, and some cases of folliculitis might be due to prolonged use of steroids along with low immune status of those patients [8], [14].

\section{Conclusion}

This study demonstrated the high incidence rate of dermatological lesions in different phases of COVID-19. Urticarial rash was the most frequent clinical pattern, especially around the trunk area. Therefore, this article confirms that skin lesions might be one of the presenting symptoms of this viral infection.

\section{Future studies}

A large-scale clinical studies involving serological testing and biopsies for patients are needed. This will tremendously assist in the early diagnosis and treatment of this novel viral infection.

\section{Acknowledgment}

We would like to thank all our colleagues from all over Iraq for their outstanding role in collecting data for this study during these difficult times.

\section{References}

1. Potekaev NN, Zhukova OV, Protsenko DN, Demina OM, Khlystova EA, Bogin V. Clinical characteristics of dermatologic manifestations of COVID-19 infection: Case series of 15 patients, review of literature, and proposed etiological classification. Int J Dermatol. 2020;59(8):1000-9. http://doi.org/10.1111/ijd.15030 PMid:32621287

2. Casas CG, Català A, Hernández GC, Rodríguez-Jiménez P4, Fernández-Nieto D, Rodríguez-Villa Lario A, et al. Classification of the cutaneous manifestations of COVID-19:A rapid prospective nationwide consensus study in Spain with 375 cases. $\mathrm{Br} J$ Dermatol. 2020;183(1):71-7. http://doi.org/10.1111/bjd.19163 PMid:32348545

3. Guertler A, Moellhoff N, Schenck TL, Hagen CS, Kendziora B, Giunta RE, et al. Onset of occupational hand eczema among healthcare workers during the SARS-CoV-2 pandemic:
Comparing a single surgical site with a COVID-19 intensive care unit. Contact Dermatitis. 2020;83(2):108-114. https://doi. org $/ 10.1111 /$ cod. 13618

PMid:32452036

4. Mahé A, Birckel E, Krieger S, Merklen C, Bottlaender L. A distinctive skin rash associated with coronavirus disease 2019? J Eur Acad Dermatol Venereol. 2020;34(6):e246-7. https://doi.org/10.1111/jdv.16471 PMid:32294259

5. Guan W, Ni Z, Hu Y, Liang WH, Ou CQ, He JX, et al. Clinical characteristics of coronavirus disease 2019 in China. N Engl J Med. 2020;382(18):1708-20. https://doi.org/10.1056/ NEJMoa2002032

6. Recalcati S. Cutaneous manifestations in COVID-19: A first perspective. J Eur Acad Dermatol Venereol. 2020;34(5):e212-3. https://doi.org/10.1111/jdv.16387

PMid:32215952

7. Young S, Fernandez AP. Skin manifestations of COVID-19. Cleve Clin J Med. 2020;2020:ccc031. https://doi.org/10.3949/ ccjm.87a.ccc031

PMid:32409442

8. Türsen Ü, Türsen B, Lotti T. Cutaneous sıde-effects of the potential COVID-19 drugs. Dermatol Ther. 2020;33(4):e13476. https://doi.org/10.1111/dth.13476

PMid:32358890

9. Schulkes KJ, Van den Elzen MT, Hack EC, Otten HG Bruijnzeel-Koomen CA, Knulst AC. Clinical similarities among bradykinin-mediated and mast cell-mediated subtypes of non-hereditary angioedema: A retrospective study. Clin Transl Allergy. 2015;5(1):5. https://doi.org/10.1186/ s13601-015-0049-8

PMid:25664168

10. Genovese G, Colonna C, Marzano AV. Varicella-like exanthem associated with COVID-19 in an 8-year-old girl: A diagnostic clue? Pediatr Dermatol. 2020;37(3):435-6. https://doi. org/10.1111/pde.14201

PMid:32315079

11. Daneshgaran G, Dubin DP, Gould DJ. Cutaneous manifestations of COVID-19: An evidence-based review. Am J Clin Dermatol. 2020;21(5):627-39. https://doi.org/10.1007/ s40257-020-00558-4 PMid:32865778

12. Kaya G, Kaya A, Saurat JH. Clinical and histopathologica features and potential pathological mechanisms of skin lesions in COVID- 19: Review of the literature. Dermatopathology. 2020;7(1):3-16. https://doi.org/10.3390/ dermatopathology 7010002 PMid:32608380

13. Hamming I, Timens W, Bulthuis ML, Lely AT, Navis GJ, van Goor H. Tissue distribution of ACE2 protein, the functional receptor for SARS coronavirus. A first step in understanding SARS pathogenesis. J Pathol. 2004;203(2):631-7. https://doi. org/10.1002/path. 1570

PMid: 15141377

14. Suchonwanit $\mathrm{P}$, Leerunyakul $\mathrm{K}$, Kositkuljorn C. Cutaneous manifestations in COVID-19: Lessons learned from current evidence. J Am Acad Dermatol. 2020;83(1):e57-60. https://doi. org/10.1016/j.jaad.2020.04.094

PMid:32339706 